\title{
無症候性頸部内頸動脈狭窄症に対するステント留置術
}

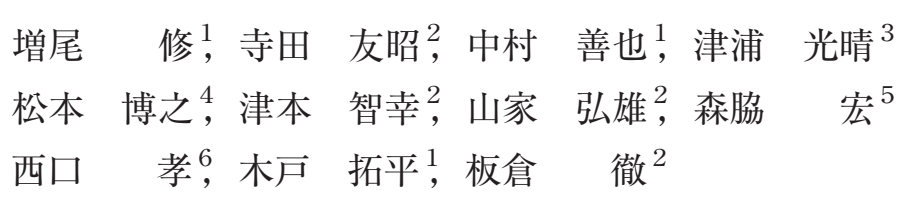

\section{Clinical Results of Carotid Stenting for Asymptomatic Carotid Stenosis}

Osamu Masuo, M.D., ${ }^{1}$ Tomoaki Terada, M.D., ${ }^{2}$ Yoshinari Nakamura, M.D., ${ }^{1}$ Mitsuharu Tsuura, M.D., ${ }^{3}$ Hiroyuki Matsumoto, M.D., ${ }^{4}$ Tomoyuki Tsumoto, M.D., ${ }^{2}$ Hiroo Yamaga, M.D., ${ }^{2}$ Hiroshi MoRiwaki, M.D., ${ }^{5}$ Takashi Nishiguchi, M.D., ${ }^{6}$ Takuhei KIDO, M.D., ${ }^{1}$ and Toru ITAKURA, M.D. ${ }^{2}$

Departments of Neurosurgery, ${ }^{1}$ Wakayama Rosai Hospital, ${ }^{2}$ Wakayama Medical Univeristy, ${ }^{3}$ Japanese Red Cross Society Wakayama Medical Center, ${ }^{4}$ Naga Hospital, Wakayama, ${ }^{5}$ Hidaka General Hospital, Gobo, and ${ }^{6}$ Hashimoto Municipal Hospital, Hashimoto, Japan

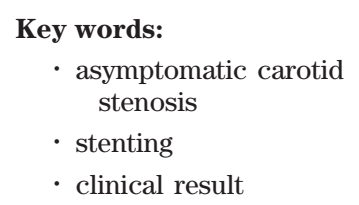

Surg Cereb Stroke (Jpn) 34: 328-333, 2006

\section{はじめに}

頸動脈ステント留置術 (Carotid Stenting; CAS) は, terectomy)に代わる治療法として出現し，ステントや末 梢塞栓の防止を目的とするプロテクションデバイスの発達 に伴う治療成績の向上とともに急速に普及しつつあ

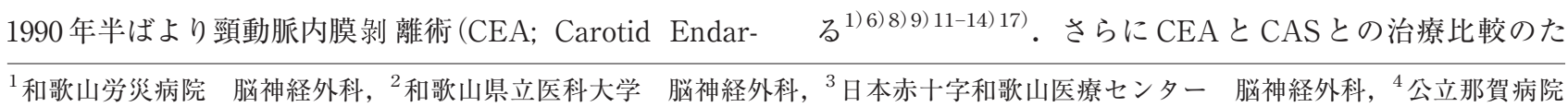
脳神経外科, ${ }^{5}$ 国保日高総合病院 脳神経外科, ${ }^{6}$ 橋本市民病院 脳神経外科 (受稿日 2005.10.5) (脱稿日 2006.1.12)〔連絡先：产 640-8505 和歌山県和歌山市古屋 435 和歌山労災病院 脳神経外科 増尾 修] [Address correspondence: Osamu MASUO, M.D., Department of Neurosurgery, Wakayama Rosai Hospital, 435 Koya, Wakayama 640-8505, Japan] 
めの大規模臨床試験も現在進行中であり，すでにCASの 優位性を証明したものもある ${ }^{16)}{ }^{18)}$ 。しかしそのほとんど が症候性もしくは CEA 高危険群のみであり, 無症候性病 変に対するCASにおいては, その適応についても施設間 でさまざまである，本論文では，われわれの施設での無症 候性病変の適応と初期, 中期成績また今後の課題について 述べる.

\section{対象と方法}

われわれの施設では 1997 年より頸部内頸動脈狭窄症に 対してステント留置術を導入し, 当初は, 全身麻酔扔よび CEA 高危険群のみを適応としていたが，プロテクション デバイスが確立された 1999 年より無症候性もその適応と し，現在では，症候性，無症候性ともに原則として $60 \%$ 以上の狭窄を有するものを CAS 第 1 選択としている．対 象は 1997 年から 2004 年 12 月までに当科および関連施設 でCAS施行された 327 症例のうち無症候性病変 114 例で ある. 平均年齢は 68.7 歳, 術前平均狭窄率は $75.6 \%$ であっ た。一方症候性病変は 213 症例で，平均年齢は 69.1 歳，平 均狭窄率は $81.5 \%$ であった。これらの症例に対しての初期 治療効果 (狭窄率の改善度, 合併症の有無, 術後 1 力月で の morbidity/mortality)，また術後 3 年を経過した 22 症例 について，中期治療効果 (治療側の虚血症状出現の有無) を検討した。

術前管理：周術期の血栓塞栓合併症を防ぐため，少なく とも2 週間前より抗血小板剂 2 郕 (aspirin $100 \mathrm{mg}$ /日と ticlopidine $200 \mathrm{mg}$ /日または cilostazol $200 \mathrm{mg}$ /日)を投与 した。

術前検査：術前検査は術中もしくは術後の合併症回避の ための危険因子把握のために重要であり，血液検査，血管 撮影, 頸動脈エコー, 脳血流検査は必須としている.

治療手技：原則として局所麻酔下に経大腿動脈アプロー チで行った．血管撮影や頸動脈エコーで，狭窄部の性状や 前後の血管の走行を把握し，塞栓予防デバイス，治療手技 を決定し，その上で片側か両側大腿穿刺のどちらで行うか を決定する，塞栓予防デバイスは，全例で blocking balloon catheter system (BBCS), PercuSurge (PS), Parodi antiembolic system (PAES), そしてフィルターデバイス である Mintcatch II のうちいずれかを使用しているが，最 近は主としてPercuSurgeを使用している。

通常，まずシース挿入後に全身へパリン化を行い，親カ テーテルを総頸動脈に留置する．狭窄末梢部に protection 用のバルーンを挿入したうえで前拡張を行う. 前拡張は主 として末梢血管径に同等のサイズの PTA バルーンで約 30 秒かけて加圧し，6-8気圧で約 30秒間の拡張を行う。徐 脈や低血圧を生じる症例では，適宜硫酸アトロピン $0.5 \mathrm{mg}$
をすみやかに静脈投与する，その後狭窄部位を十分カバー するようにステントを留置し, protection下に貯留してい る栓子を吸引，さらに外頸動脈に洗い流す。拡張不十分な 症例は必要に応じて後拡張を追加している。

$\mathrm{BBCS}^{1112) 14)}$ ， $\mathrm{PS}^{13)}, \mathrm{PAES}^{6)}$ の方法については，すで に当科より紹介されているので割愛するが, 機材の選択は, 狭窄病変の形状に応じて選択しており，PAESは血栓を伴 った病変や偽閉塞性病変など狭窄部を通過させる際に， distal embolismを起こす可能性が高い病変で使用してい る. Mintcatch II は，発売後まだまもないため，当科では 試験的使用のみとしており，狭窄の程度が高度でなく，前 後の血管が屈曲していない症例に使用している.

術後管理：術後は 24 時間持続でヘパリンまたはアルガ ドロバンの投与を行った。また術後 2-5 日の間で DWI (diffusion weighted image; 拡散強調画像)を施行し，末梢 塞栓の有無を確認した。

\section{結 果}

\section{ステント留置術数の推移}

Fig. 1 は和歌山医大および関連施設における年毎の頸動 脈ステント留置術の推移を示したものである.CASを導 入した 1997 年当初は, 症候性かつ CEA 高危険群のみをそ の適応としていたが，2000年に頸動脈狭乍症に対してス テント第 1 選択としてから以降，その数も増加してきてい る．無症候性症例についても徐々に増加していたが，2004 年やや減少した。これは適応を後述の理由でやや絞った結 果と思われる。一方 2001 年以降，CASが選択されずに CEA が選択された無症候性病変が 5 例あった。内訳は 60 歳未満の若年者で，かつ低位狭窄病変のため CEA が比較 的容易と考えられた 3 症例，また proximal protectionが

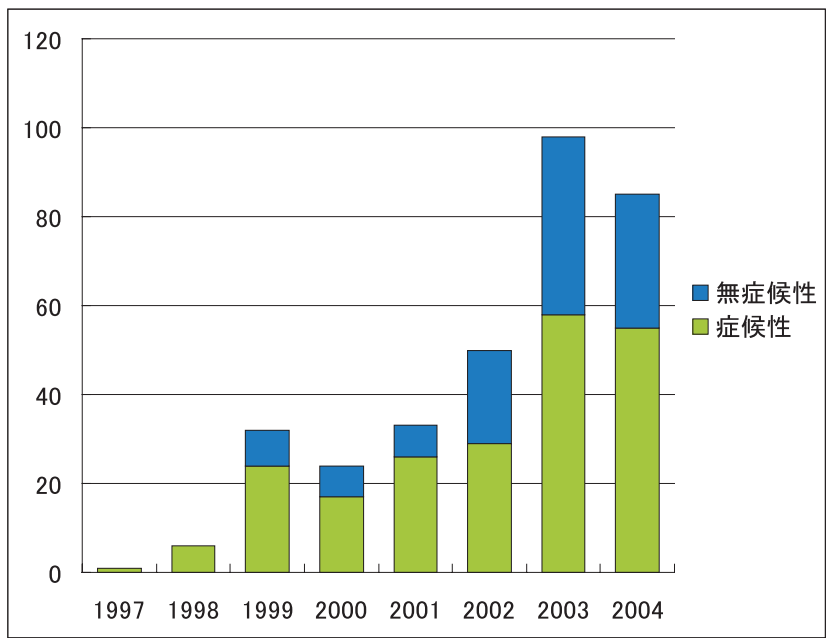

Fig. 1 Change of numbers for CAS at Wakayama prefecture. 
Table 1 Clinical results of CAS for aymptomatic and symptomatic carotid stenosis

\begin{tabular}{lcc}
\hline & 無症候性 & 症候性 \\
& 114 症例 & 213 症例 \\
\hline 平均年齢 & 68.7 歳 & 69.1 歳 \\
術前狭管率 & $76.7 \%$ & $81.2 \%$ \\
術後狭乍率 & $5.6 \%$ & $5.5 \%$ \\
合併症 & $1 / 114(0.8 \%)$ & $12 / 213(5.6 \%)$ \\
$\quad$ 虚血性合併症 & 0 & 9 \\
$\quad$ 症候性塞栓性 & 0 & $5 / 9$ \\
過潅流症候群 & 1 & 1 \\
コレステロール塞栓 & 0 & 2 \\
Morbidity (術 30 日後 & 1 & 5 \\
$\quad$ major & 0 & 2 \\
$\quad$ minor & 1 & 3 \\
Mortality (術 30 日後) & 0 & $7 / 213(3.2 \%)$ \\
Morbi/mortality & $1 / 114(0.8 \%)$ & 5 \\
再狭窄 & 3 & $1 / 73$ \\
虚血症状出現症例 & $0 / 22$ & \\
$\quad$ (術 3 年以上) & & \\
\hline
\end{tabular}

確立されていない時期での，血栓を伴った狭窄性病変で， distal protectionでは狭窄部通過時に末梢塞栓をきたす可 能性が高いと判断された 1 症例, 大動脈弓からのアクセス ルートに問題があった 1 症例であった。

\section{初期治療成績}

無症候性病変 (114 症例, 平均年龄 68.7 歳) では術前平均 狭窄率は $76.7 \%$ であり術後 5.6\% に改善した (Table 1). 一 方症候性病変 (213 症例, 平均年龃は 69.1 歳) では術前平均 狭窄率は $81.2 \%$ であり, $5.5 \%$ に改善しており, 術前狭窄 率はやや症候性で高かったものの, 術後残存狭窄率はほぼ 同等であった。

\section{Protection Device}

無症候性狭窄病変に対しては, 全例でいずれかのプロテ クションデバイスを使用している.内訳は後拡張のみで BBCS を使用 (13 例), 前拡張, 後拡張ともに BBCS 使用 (23 例)，PercuSurge使用 (71 例)，PAES 使用 (3 例), Mintcatch II (4例)であった. 時代の変遷とともにそのデ バイスも変化してきているが, 現在では主として PercuSurge を使用している.

\section{周術期合併症}

Table 1 に周術期合併症, 再狭窄, 術 3 年以上経過した 症例での虚血症状出現数を示している. 症候性塞栓性合併 症については, 症候性狭窄性病変 213 例中 5 例で認めた
（うち 3 例は protection deviceは使用していなかった）の に対し，無症候性病変では，症候性塞栓性合併症は認めな かった。無症候性狭窄性病変では, 術 30 分後に hyperperfusionによる痤攣，脳出血をきたし，軽度右片麻痺を後遺 した症例を 1 例経験した。術 30 日後の morbidity/mortalityは 114 症例中, 先述した hyperperfusion の症例 1 例で あり， $0.8 \%$ であった。

\section{中期治療結果}

術後 3 年を経過した 22 症例のうち患側の虚血症状をき たした症例はなく $0 \%$ であった。なお症候性病変では，ス テント留置 5 年後に患側中大脳動脈閉塞をきたし, 左片麻 痺を後遺した 1 例を経験している。

\section{代表症例呈示}

〈症例 1〉74歳, 男性.

心房細動による脳塞栓 (左中大脳動脈閉塞)で当院を救 急受診された。血栓溶解療法で神経学的に後遺症なく回復 されたが，その際に右内頸動脈が仮性閉塞であることが判 明したため(Fig. 2A), ステント留置術を予定とした. 右 内頸動脈撮影では, 狭窄部は不整であり, PercuSurge で は通過困難と考え, PAESによる proximal protection下 で行うこととした。右大腿動脈, 左大腿静脈にそれぞれ $11 \mathrm{Fr}$., 5Fr. シースを挿入し, 全身へパリン化のうえ, 親 カテーテルである LILACを右総頸動脈に留置した.さら に上甲状腺動脈とともに外頸動脈をCATTLEYA で閉塞 させ, reverse flowが得られていることを確認したうえで, Choise PT (Boston Scientific)を末梢に挿入し，これを軸 に Amiia (Cordis, Johnson\&Johnson) $4.0 \mathrm{~mm} \times 3 \mathrm{~cm}$ で前 拡張を行い(Fig. 2B), その後Precise (Cordis, Johnson\& Johnson) $9 \mathrm{~mm} \times 4 \mathrm{~cm}$ を留置した.その後のIVUSで一部 拡張不十分であったので, Amiia $4.5 \mathrm{~mm} \times 2 \mathrm{~cm}$ にて後拡 張を加えた. 術後の血管撮影(Fig. 2C)では，十分な拡張 が得られ, 術後の DWIでも高吸収域は認めなかった。

〈症例 2〉74歳, 男性.

上肢血圧の左右差 $30 \mathrm{mmHg}$ あるとのことで当科紹介さ れた．血管撮影で左鎖骨下動脈狭窄 $(70 \%)$ と同時に右内頸 動脈狭窄 (80\%)（Fig. 3A）がみつかった。まず症候性の鎖 骨下動脈狭窄症に対してPalmazステント Cordis, Johnson\&Johnson) を留置し, 後日無症候性の頸動脈狭窄 症に対してステント留置術を予定した。右大腿動脈に 9Fr.Brite tipを留置し, PercuSurgeによるdistal protection下で Savvy (Cordis, Johnson\&Johnson) $4.5 \mathrm{~mm} \times 4$ $\mathrm{cm}$ で前拡張したのち, SMARTer (Cordis, Johnson\& Johnson) $8 \mathrm{~mm} \times 6 \mathrm{~cm}$ を留置した。術後の血管撮影 (Fig. 3B)では, 十分な拡張が得られ, 術後のDWIでも高吸収 

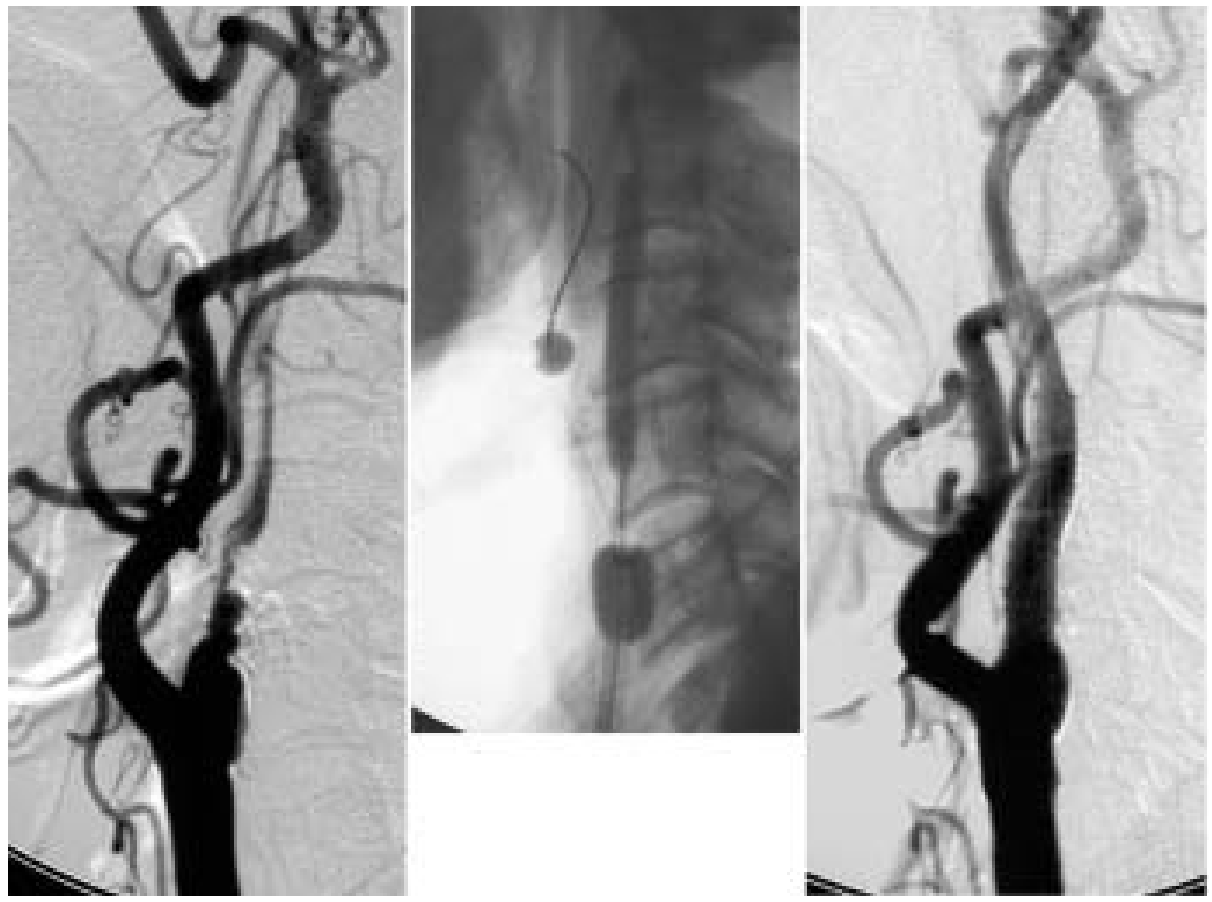

$\mathrm{A}|\mathrm{B}| \mathrm{C}$

Fig. 2 A: Right carotid angiogram shows right ICA near occlusion.

B: Pre-dilatation using ParodiAnti-embolic system

C: Right carotid angiogram after CAS demonstrates sufficient dilatation.
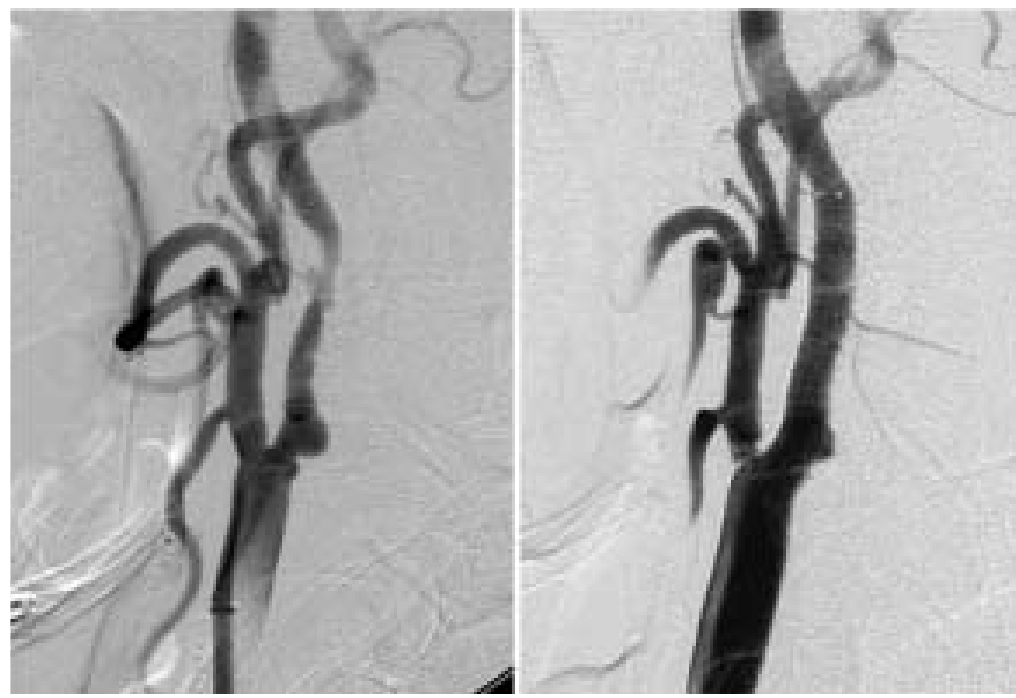

$\mathrm{A} \mid \mathrm{B}$

Fig. 3 A: Right carotid angiogram shows $70 \%$ stenosis at carotid cervical portion. B: Right carotid angiogram after CAS demonstrates to alleviate stenosis.

域は認めず，神経脱落症状なく退院された。

\section{考察}

頸部内頸動脈狭窄症に対するステント留置術は, 頸動脈 内膜剝離術 (Carotid Endarterectomy; CEA) に代わる治療 法として，1990年半ばより相次いでその有効性を示す報
告がなされた 1)6)899)11-14)16-18)．またその治療成績も，自 己拡張型ステントや塞栓予防デバイスの開発により格段に 向上している．1997年より開始されたWholey ${ }^{15)}$ によ る World wide registry からの最新報告によるとCASを施 行された 12392 症例において, 残存狭窄が $30 \%$ 未満の technical successful rateは $98.9 \%$ と高く，また手技に伴 
う合併症率は $3.98 \%$ であった。さらにその中で塞栓予防デ バイスを用いた 4221 症例に限れば $2.23 \%$ とさらに良好な 結果が示されており, CEAの内科的治療に対する優位性 を保つための周術期合併症率をすでに下回っていることが 示されている。 また術後 3 年経過症例での患側脳梗塞の出 現率は $1.7 \%$ と良好であった ${ }^{15)}{ }^{16)}$ 。また CEA と CAS とを 比較する種々の大規模なランダム化試験も現在進行中であ り，すでにCASの優位性を示したものもある.SAPPHIRE studyでは症候性で $50 \%$ 以上，無症候性で $80 \%$ 以 上の CEA 高危険群を対象としたランダム化試験である が, 治療合併症 (30日以内の脳梗塞, 死亡, 心筋梗塞抒よ び 1 年以内の患側脳梗塞の出現) が CAS は $12.2 \%, C E A$ は 20.1\%であり，有意差をもってCASの優位性が示され， 同時に 1 年以内の再狭窄に対する再治療率においても CAS の優位性も示された ${ }^{17)}$. 当初 CEA 高危険群を対象に 始められたCASであるが，前述したランダム化試験をも とに今後も大いに発展していく可能性がある.

一方で無症候性病変については, 現時点では厳密な適応 基準がなく，CEAの適応に準じるのが一般的である．無 症候性病変における CEA の優位性が証明された $\mathrm{ACAS}^{4)}$ に準じて狭窄率 $60 \%$ 以上とする施設と, AHAのガイドラ イン ${ }^{7)}$ に従って狭窄率 $80 \%$ 以上とする施設があり，われ われは末梢塞栓防止デバイスが確立された 1999 年以降, 原則として前者を適応基準としてきた. ただし最近は，中 等度の狭窄 (60-70\%)の症例に対しては, 潰瘍を伴ってい るなど, 脳卒中発症の risk が高いと思われる症例に限っ ている．またわれわれの施設では，周術期合併症で最も問 題とされる血栓塞栓合併症を予防するために，画一的な手 技, 器材にこだわらず, 個々の症例の狭窄度, 狭窄部の屈 曲の程度, 性状を十分把握したうえで protection device を含めた各種器材の選択について術前に十分な検討を行っ ている. その結果, われわれの経験した無症候性 114 症例 の結果では周術期合併症は術後 hyperperfusion による脳 出血をきたした 1 例のみであり, 幸いにも血栓塞栓合併症 はなかった。また 3 年経過した 22 症例においても患側に 脳梗塞をきたした症例は認めなかった. Brooksらは, 無 症候性である 43 症例で, 5 例に術後徐脈, 低血圧が出現 したものの, 神経学的に後遺症を起こしたものは 0 であっ たと報告している ${ }^{2)}$.また Sherif らの報告では $70 \%$ 以上 の無症候性頸動脈狭窄病変患者 421 例で, $7 \%$ とやや高め の周術期合併症であった ${ }^{10)}$. 自験例の結果や前述した各 報告をみても，無症候性頸動脈狭窄症に対するCAS の治 療成績は, CEA と少なくとも同等あるいはより良いと考 えられる.さらにCEAに比して通常全身麻酔を必要とし ないこと, 頸部切開が必要なく患者にとって低侵襲である こと, 他部位の血管性病変も場合により同時治療が可能な
ことなどのアドバンテージを考慮すれば，CASが今後無 症候性頸動脈狭乍症の治療においても主役となる可能性は 大いにあると考えられる.さらに日進月歩で進歩を遂げて いるデバイスにより当初 CEAを選択されていた症例も現 在ではCASでも対応できるようになっており，現時点で われわれは前拡張で十分に拡張を得られない全周性石灰化 を伴った狭窄病変および頚動脈へのアクセスが困難な症例 をCEAの適応と考えている。

また無症候性頸動脈狭窄症の natural historyについて の論文が近年になり散見されるようになったが3)5, Inzitari らは, 狭管率が高度になるに比例して脳卒中発生 危険度も上がるとしているものの，その脳卒中の内訳は 45\%がラクナ梗塞または心原性塞栓であったとしてい $る^{5)}$.つまり実際の頸動脈病変との関連性が薄いと考えら れる脳卒中が含まれているがために，CEAにおける有益 性が過大評価されているとしている，つまり抗血小板療法 を中心とした内科的治療でも予後は十分良いものであると いうことである．さらにその内科的治療においても抗血小 板剂だけでなく，各種降圧剤，スタチン製剤などを加えた “best medical treatment”がCEAに対する randomized trialが相次いで報告された時代に比して格段に進歩して いる3). 実際に 2004 年, 米国で頸動脈狭窄症に対して CASが認可されたが, SAPPHIREに準じて無症候性病変 に対しての適応は $80 \%$ 以上狭窄との制限がなされた。 Sherif らも $80 \%$ 以上狭窄の無症候性頸動脈狭窄症のみに CASの利益があると報告している ${ }^{10)}$.

ここ数年においても, protection deviceやステントなど 器材の進歩はめざましいものがあり, 今後 CAS の症例数 増加だけでなく治療成績の向上も大いに期待できるが，狭 窄度に応じた脳卒中出現率を含めた自然経過，さらに現時 点での “best medical treatment”での内科的治療と CAS を施行した症例との比較するような RCT が今後必要と考 えられる。

\section{結＼cjkstart語}

無症候性頸部内頸動脈狭窄症に対するステント留置術の 治療成績は良好であり，脳梗塞予防という点からも有効性 が示された。今後は自然経過をふまえたうえでの RCTが 必要であり, 治療適応の確立が課題である.

\section{文献}

1) Albuquerque FC, Teitelbaum GP, Lavine SD, et al: Balloon-protected carotid angioplasty. Neurosurgery 46: 918-923, 2000

2) Brooks WH, McClure RR, Jones MR, et al: Carotid angioplasty and stenting versus carotid endarterectomy for treatment of asymptomatic carotid stenosis: a randomized trial in a community hospital. Neurosurgery 54: 318-325, 
2004

3) Coccheri S: Asymptomatic carotid stenosis: natural history and therapeutic implications. Pathophysiol Haemost Thromb 33: 298-301, 2003

4) Executive Committee for the Asymptomatic Carotid Atherosclerosis Study: Endarterectomy for asymptomatic carotid artery stenosis. JAMA 273: 1421-1428, 1995

5) Inzitari $\mathrm{D}$, Eliasziw $\mathrm{M}$, Gates $\mathrm{P}$, et al: The causes and risk of stroke in patients with asymptomatic internal-carotidartery stenosis. North American Symptomatic Carotid Endarterectomy Trial Collaborators. $N$ Engl J Med 342: 1693-1700, 2000

6) 増尾 修, 寺田友昭, 中村善也, ほか: 頸部内頸動脈狭窄 症に対するステント留置術一治療手技での工夫と治療成績 一. 脳卒中の外科 33: 244-248, 2005

7) Moore WS, Barnett HJ, Beebe HG, et al: Guidelines for carotid endarterectomy. A multidisciplinary consensus statement from the ad hoc Committee, American Heart Association. Stroke 26: 188-201, 1995

8) Phatouros CC, Higashida RT, Malek AM, et al: Carotid artery stent placement for atherosclerotic disease: rationale, technique, and current status. Radiology 217: 26-41, 2000

9) Roubin GS, New G, Iyer SS, et al: Immediate and late clinical outcomes of carotid artery stenting in patients with symptomatic and asymptomatic carotid artery stenosis: a 5-year prospective analysis. Circulation 103: 532-537, 2001

10) Sherif C, Dick P, Sabeti S, et al: Neurological outcome of conservative versus endovascular treatment of patients with asymptomatic high-grade carotid artery stenosis: a propensity score-adjusted analysis. J Endovasc Ther 12: $145-155,2005$

11）寺田友昭, 津浦光晴, 松本博之, ほか: 頸部内頸動脈狭窄 症に対する血管内治療の実際。脳卒中の外科 30: 75-82, 2002

12) Terada $T$, Tsuura $M$, Matsumoto $H$, et al: Results of endovascular treatment of internal carotid artery stenosis with a newly developed balloon protection catheter. Neurosurgery 53: 617-625, 2003

13）寺田友昭, 津浦光晴, 松本博之, ほか: 頸部内頸動脈狭窄 症に対する血管内治療の基本手技. 脳外誌 13: 126-133, 2004

14）津浦光晴, 寺田友昭, 松本博之, ほか: 頸部内頸動脈狭窄 症に対するステント留置術の治療成績. 脳卒中の外科 31 : 129-133, 2003

15) Wholey MH, Wholey M, Mathias K, et al: Global experience in cervical carotid artery stent placement. Cathet Cardiovasc Intervent 50: 160-167, 2000

16) Wholey $\mathrm{MH}$, Al-Mubarek N, Wholey MH: Updated review of the global carotid artery stent registry. Cathet Cardiovasc Intervent 60: 259-266, 2003

17) Yadav JS, Stygall J, Lunn S, et al: Elective stenting of the extracranial carotid arteries. Circulation 95: 376-381, 1997

18) Yadav JS, Wholey MH, Kuntz RE, et al: Stenting and angioplasty with protection in patients at high risk for endarterectomy investigators: Protected carotid-artery stenting versus endarterectomy in high-risk patients. $N$ Engl J Med 351: 1493-1501, 2004 